\title{
The Social Question in the Middle East
}

\author{
Past and Present
}

Kevan Harris

In 1840, a coalition of European powers decided to take on an alarming problem to their south. The Albanian-born governor of Ottoman Egypt, Mehmed Ali, had spent the past two decades building up a formidable industrial and military capacity among his assigned territories. A veteran of the Napoleonic wars, the Wahhabi revolt, and the Greek rebellion, Ali administered Egypt as a province of the Sublime Porte in name only; in reality, he was forging a Mediterranean Prussia. Ali's troops marched on Palestine, Syria, and then Greece, claiming territory and stationing men. The Ottoman sultan could do little about it. Eventually, the British and Austrian navies cut off Egyptian supply lines and entered Alexandria's waters. Ali signed a series of capitulations under duress that opened Egyptian markets, dismantled its manufacturing base, and defanged its military. Egypt experienced rapid underdevelopment, becoming an exporter of raw commodities and an importer of European manufactures for the next century. ${ }^{1}$ It was not until the rule of Gamal Abdel Nasser that such statist attempts would occur again in North Africa, to be met again with external military response. Today, not coincidentally, Egypt lags behind other middle-income states in industrial capacity, and it is the world's largest importer of wheat.

Amid these mid-nineteenth-century efforts of geopolitical renewal, writers such as the Egypt-based intellectual Rifa'a al-Tahtawi attempted a synthesis of Islamic political thought and European political economy. ${ }^{2}$ Qasim Amin's The Liberation of Women and The New Woman appeared not long after. Though the actors have changed since al-Tahtawi and Amin paid heed to the emerging social question in relation to state building, the debates over the prospects for regional order, popular cohesion, and political rejuvenation remain largely unaltered. To chart 
the historical terrain, this chapter provides a survey of social regulation and political economy for states in Middle East and North Africa (MENA), amid changing political-economic conditions, across five broad chronological periods: the tail end of the Ottoman and Persian Empires, the colonial interlude, the era of political independence, the infitah years of economic opening, and the current upheaval of unrest and militarization.

\section{EMPIRES UNRAVELED}

Notwithstanding the lack of a settled conceptual or geographic definition for the region itself, few zones of the world have been placed in opposition for so long than Europe and the Middle East. Mostly recently, the institutional turn in economics has produced attempts to explain anew the divergence between them. These accounts focus on the persistence of "bad" institutions in MENA areas over the longue durée-lack of primogeniture, for instance, or dominance of state rulers over local elites. ${ }^{3}$ Yet economic historians of the region counter that institutional pluralism, not uniformity, was the rule. Land-tenure patterns ranged from small peasant holdings to tax farming by notables to imperially administered estates. Commerce and credit tended to flow through and between urban locales, overcoming or bypassing religious dictates against usury through flexible interpretations of scripture; women's and religious minorities' roles as traders were not insignificant. Nomadic tribal confederations ranged across large swaths of the region, coexisting within and around agrarian empires and their urban metropoles. The "gunpowder empires" of the early modern period-as Marshall Hodgson termed the Ottomans and Safavids-more successfully centralized a ruling apparatus and market penetration over large territories compared to previous centuries. Long before Western colonialism, the internal and external borders marked out by these and subsequent warring empires laid the foundations for twentiethcentury state-building in the MENA region.

As elsewhere, the internal authority of these empires was irregularly exercised. By the end of the eighteenth century, merchants, artisan guilds, and religious endowments tended to administer most social aid and welfare in imperial urban zones. Charitable giving was, of course, an Islamic injunction. Through the pooling of donations and assets under religious endowments, Hodgson noted, "various civic essentials and even amenities were provided for on a private yet dependable basis without need or fear of the intervention of political power." ${ }^{4}$ Yet the few studies that exist show that inequality was quite high in West Asian empires. The Gini index during the eighteenth century for sampled records in Cairo and Damascus hovered around 0.75, while northern Anatolian locales stood at 0.60.5

There was no generalized effect from increased commercial trade with the capitalist world economy and penetration by European merchants and militaries in 
the region. The variation of peasant tenure patterns, merchant-state relations, and artisan-guild politics widely differed, based on relations between local elites and imperial centers. Hardly the paragon of "Asian despotism," Ottoman capacity for state regulation was, in fact, limited and reached its apex in the sixteenth century. Most revenues were kept by tax-farming notables, while merchant entreaties against foreign competition from European trade went largely unheeded. ${ }^{6}$ The recentralization of the Ottoman bureaucracy through nineteenth-century reforms brought the state back into social regulation and class formation, most notably in Mehmed Ali's Egypt and the wealthier Ottoman provinces.7 The Persian Empire under the Qajar dynasty fared worse at fiscal-military centralization, as evidenced by a series of famines during the 1860 os and 1870 s. During these catastrophes, an imperial ban on cereal exports was mandated but unenforceable. Most of the famine aid came from European missionaries, not the imperial government in Tehran, and was directed toward religious minorities. ${ }^{8}$

Given the unevenness of state penetration combined with social deprivation, it is not surprising that unrest broke out. The nineteenth century witnessed a wave of uprisings on MENA imperial peripheries that Eric Hobsbawm would have instantly recognized as led by primitive rebels: the Sudanese Mahdi, the Daghestani Imam Shamil, the Shirazi Bab (precursor to Bahaism), the Sokoto's Usman dan Fodio (across the Sahara along the Niger), or the Somaliland's Mohammad Abdullah Hassan (the original "Mad Mullah"). These were generally millenarian movements that devised radical worldviews and appealed to social justice under the guise of Islamic tradition. Whether quickly extinguished or successfully converted into proto-states, their presence was often the pretense for intervention of Western colonial armies.

The inability of MENA empires to confront external and internal challenges spurred urban intellectuals to argue for more radical social and political measures to be carried out by the state. Along with other agrarian empires, such Russia, India, and China, the Ottomans and Persians underwent anti-imperialist revolts at their urban centers in the early twentieth century. The dynamics were similar: elites attempted to redirect their remaining imperial resources toward military upgrading, popular mobilization, and nationalist myth-making, often combined with a degree of emancipation for women of the elite, at least. ${ }^{9}$ It is not a coincidence that the first successful attempt occurred at the heart of West Asia's imperial arena: Kemalism. The MENA social compacts of the mid-twentieth century owed much to its example.

\section{THE COLONIAL INTERLUDE}

The exercise and profile of European power in the Middle East and North Africa varied by subregion. The British pushed Napoleon's army out of Egypt, but the restored Bourbons entered Ottoman Algeria in the 1830 s and forcefully integrated 
territory into the French state. For most of the region, in contrast with sub-Saharan Africa, inter-imperialist rivalries slowed the formal usurpation of power. The British viewed a contained Ottoman empire as a useful bulwark against Russian expansion. Tunisia fell to French gunboats only in the 1880s; Morocco, which had always maintained independence from the Ottomans, was partitioned into French and Spanish protectorates in the 1910s. The priority of British imperial policy in the MENA expanse was geopolitical control over travel routes to South and East Asia. The Persian Empire slowly lost territory during the nineteenth century to Russian and British incursions, but never formal independence, largely for this reason. ${ }^{10}$ In fact, there was only one direct colony established over two centuries of European imperialism in the region-the port of Aden on the Yemeni coast, ruled as part of British India.

European capital was less hobbled. French and British banks financed Ottoman state reforms in the mid-nineteenth century, which put them in sound position after the Ottomans defaulted. Eventually a European consortium took over Ottoman finances in the late nineteenth century, an arrangement that was, unsurprisingly, favorable to creditors. ${ }^{11}$ The vehicle of debt arrears furthered British machinations for control over the Suez Canal and indirect rule in Egypt and Sudan. As with Iran, the Maghreb region from Morocco to Egypt was racked with famines in the 1870s. A prime culprit lay partly in the shift to monocropped agriculture-usually wheat and cotton exports-which had suffered from American competition and declining terms of trade during the global depression of the late nineteenth century. ${ }^{12}$ Yet even amid minor British and French imperial efforts at fostering plantation agriculture, a small landholding peasantry persisted throughout most of the Ottoman empire into the early twentieth century.

A crucial analytic point for the MENA region, then, is that European imperialist penetration of political and social structures was highly uneven. So was Ottoman rule, of course-some stretches of the Libyan coast were limited to trading posts for warding off Bedouin raids. After the Ottoman Empire shattered in World War I, some areas were ruled by mandate administration, others in an indirect fashion, and other areas won formal independence through rebellion. Though vogue, it is hyperbolic to believe that a Franco-British colonial order created the modern Middle East; such an order rather cobbled together structures of rule out of a diverse Ottoman-Persian imperial zone. As this zone collapsed on itself during the early twentieth century, elite-led nationalist movements of both minority and majority varieties-such as Greeks, Serbs, Armenians, Kurds, Turks, Arabs, and Maronites-maneuvered among the ruins. ${ }^{13}$ Some of these intelligentsias converted into state rulers; others formed the transnational diasporas that today reside in Western metropolises.

The interwar period drew together the challenges of external colonial imposition and domestic political rejuvenation in contradictory relation to the social question. In British and French administered territories such as Egypt or Syria, 
nationalist elites mobilized on social as well as political grounds. In areas where the colonial question was largely settled, as in interwar Turkey or Iran, splits appeared earlier between nationalist elites and labor movements. ${ }^{14}$ Unlike Latin America, where the interwar years provided a spur toward industrialization, in Europeancontrolled MENA the emphasis was on regulating the safe flow of goods through the region. Early oil discoveries in Khuzestan, Baku, and Kirkuk added to such imperatives.

Though the geopolitical priority was control over transit, inter-European rivalries allowed for acquisition of capital goods in trading zones. Industrial production finally resumed as another world war loomed, leading to increased proletarianization in mandate-administered urban centers. The irony is that, while a Bismarckian state-led development project had commenced under the guise of an anti-imperialist push for independence in the newly forming nation-states of Turkey and Iran, similar processes were occurring under British and French colonial administration. Unlike independent states, however, less was spent on welfare and public works by colonial elites, and nascent industrial drives remained based in enclave areas.

The period from the 1900 s to the 1940 s forged another of the great ironies of modern Middle Eastern history. Amid crises of domestic authority, transnational networks of intellectuals_religious and secular, liberal and communist-created a common set of frameworks for nation building, myth making, and postcolonial citizenship (industrial Japan was a widely held exemplar). Their eventual success in forming coherent nation-states out of imperial clay would result in the erasure of the memory of their own roles. The transmissions of pamphlets, laborers, and revolutionaries along the paths of Istanbul-Tabriz-Baku-Tashkent or CairoDamascus-Baghdad were possible only in a late imperial milieu of cosmopolitanism. Bolstered by armed uprisings and mass organizations, these energies poured into the containers of the state over subsequent decades. Yet once the actual work of state building commenced, political theory was not easily translated into practice. If there is a common lesson for MENA states in the interwar and postwar periods, it is the failure of elitist liberalism and the success of popular mobilization for the purposes of state building. With a freer hand, Kemalist Turkey and Pahlavi Iran had already engaged in such efforts during the 1930s. The Wafd (delegation) Party in Egypt achieved popular appeal while under British protectorate status, but it focused doggedly on independence at the expense of a radical mass agenda. European interwar left movements were of little help-the 1936 French popularfront government refused independence to Syria, Lebanon, and Algeria.

Once decolonization set in, however, a region-wide social compact began to coalesce. To map out its contours, a contrast with Latin America is useful. During the 1930 sise of populist states in Brazil, Argentina, and Mexico, public goods and social citizenship were extended de jure to the entire citizenry. Latin American elites crafted nationalist appeals to mestizaje or racial democracy, which attempted 
to reverse the stark colonial legacies of ethno-racial classification under slavery and indigenous servitude. Yet de facto distribution of these public goods tended to fall along preexisting hierarchical lines of social distinction. Unequal access to basic health care, education, and infrastructural improvements led to the notoriously high inequality observed within much of twentieth-century Latin America. ${ }^{15}$ In the MENA region, the opposite occurred, due to the postwar configuration of state formation though corporatism.

\section{THE POSTWAR CORPORATIST COMPACT}

Initially welcomed by newly independent states, postwar U.S. hegemony was doubly edged in the MENA region. On the one hand, the lack of major U.S. corporate interests compared to Latin American markets meant that U.S. policy makers largely encouraged import substitution and aided state-led development during the 1950 and early 1960 s. On the other hand, U.S. geopolitical strategy of securing favorable access to oil resources through informal alliances laid the foundation for a subsequent direct militarization of vital MENA areas. The Cold War context and its coalescing divides masked a widely shared approach to social compacts in the postwar era. No matter the ideological sheen, state-led planning amid scarcity of capital ruled the day. This was the context for nationalization projects from Nasser in Egypt to Mossadeq in Iran. Resources could be mobilized through maneuvering among Cold War alliances, but claims of a distinctive model of "Arab socialism" were partly aimed at warding off or co-opting the growing power of left-wing movements. ${ }^{16}$

The Turkish example loomed large. In response to the chaos of Ottoman collapse and radical domestic upsurges, the Kemalist Republic forged its own authoritarian version of Polanyi's double movement in the 1930s and 1940s: Sovietinspired five-year industrialization plans, Italian-inspired corporate labor control, and U.S.-inspired distribution of state lands to middle peasants and large landowners. As a result, the decentralized land-tenure patterns in Ottoman Anatolia were, even into the 1960 , preserved. ${ }^{17}$

For the new nation-states of the MENA region, this corporatist model of industrialization allowed a newly emergent political class to undercut the power bases of economic and social rivals. Iran's Pahlavi monarchy built up a military and bureaucratic corps in the 1930s, a concentrated industrial class in the 1960s, and only afterward began to force landowners to divest their holdings of village lands. The shah compared what he labeled Iran's 1960s "White Revolution" with the examples of Meiji Japan and Bismarckian Prussia. ${ }^{18}$

Other countries took the same approach in speedier fashion, thus appearing all the more radical. Unlike Anatolia, in Egypt, Iraq, Tunisia, and greater Syria, land enclosures by tribal chiefdoms and landlords had intensified during the early-twentieth-century imperial breakdown. The longevity of new Arab states, 
therefore, was connected to how their leaders dealt with the social question in the countryside. Sixty percent of the Egyptian peasantry was landless in 1950, the same ratio existed in Syria, and Iraq's tribal areas were racked with peasant revolt. In Algeria, an extreme case of proletarianized rural wage labor policed by colonial arms remained in existence.

These were not traditional social structures inherited by postwar states, but rather a product of rapid consolidation by local agrarian elites that dislocated segments of the population. As Hanna Batatu explained, "Extensive tracts of state domain and communal tribal land passed into the hands of new men of capital, European colons, ex-warring shaykhs, or retainees of ruling pashas, often through forced purchases or without ground of right or any payment whatever." ${ }^{19}$ Under this politics of notables, sometimes with liberal democratic guises, peasants were displaced from kinship networks and communal mechanisms of social reproduction. Amid these fraying ties, the revolutionary Arab state promised to step in-Egypt in 1952, Tunisia in 1957, Iraq in 1958, Algeria in 1962, Syria in 1963, and Libya in 1969, not to mention revolutionary guerrilla movements in Oman, Lebanon, Yemen, and Jordan from the late 1960 s onward. To a large extent, the social origins of this new power elite were rural or provincial men who had risen up through military and other state institutions. The goal was not a peasant revolution, however, but a Kemalist revolution to be carried out by bureaucrats from above. Democracy was largely seen as a divisive distraction from the task of state consolidation.

These processes are often jumbled together under an umbrella category of clientelist rule or neo-patrimonialism, sometimes claimed to be a fixed legacy of Ottoman sultanism in Arab lands. But as James Gelvin notes, this line of argument tended to reveal more about mid-twentieth-century historians and social scientists than the actual region itself. ${ }^{20}$ As Gelvin saw it, Arab corporatism was a form of class warfare. Not between capital and labor, but between the new state elite and the old oligarchical landed classes. To some degree, the repressive apparatus of many MENA states stem from this rapid and stealthy capture of political power by men of rural lower-middle class backgrounds, such as Nasser and Hafez al-Assad. Forever paranoid of retaliation by enemies, real or conjured, these men first deployed security forces against the "feudal" elite and the same apparatus was subsequently marshaled against any perceived threat of ouster.

The incorporation of peasant, worker, and professional strata into state-linked bodies provided a countervailing social base from which to break up landholdings and dismantle mercantile networks. As a result, rural peasants were not emancipated as a class, but many of their children ended up in public employment in the city. A key outcome of the corporatist model-ideological patinas about rule of the masses aside-was the provision of rapid upward social mobility for select individuals. As Gilbert Achcar stressed, "the state went so far as to largely substitute itself for the private sector by means of both far-reaching nationalization programs and 
massive public investment." ${ }^{21}$ The average annual rate of manufacturing growth among MENA states was 13.5 percent in the 1950 s and 10.6 percent from 1960 to 1973. In the realm of social protection, non-state charities and philanthropies of the liberal interwar period-schools, workshops, clinics-were eventually taken over by the state and homogenized. ${ }^{22}$

The social compact involved a huge push in credentialing citizens through education and high status professional-technical employment. The Nasser period in Egypt (1954-1970), for example, saw primary school enrollment rise by 234 percent and higher education by 325 percent. ${ }^{23}$ Education was the path of least resistance for many of these states to reduce preexisting class privileges and reorder status hierarchies. It also was a tried-and-true method of creating loyal citizens who identified with the nation-state's imagined community more than its competitors.

Once in place, the MENA state-led social compact had an impressive impact on livelihoods over the next three decades. The World Bank deemed the model as "rapid growth ... and generous transfers to large parts of the population." From 1960 to 1985 , Arab states outperformed all other Third World regions except East Asia in income growth with equitable income distribution. Infant mortality was cut in half, life expectancy increased by ten years. As far as we can trust internationally comparable poverty lines, MENA became a relatively low-poverty region in the Global South: 5.6 percent of the population lived under the $\$ 1$ per day purchasing power parity (PPP) line in 1990 versus 14.7 percent in East Asia and 28.8 percent in Latin America. ${ }^{24}$ The same can be broadly said for internal inequality. Though household surveys in MENA tend to measure consumption, not income, Gini levels of inequality in the region floated around 0.35 to 0.50 , well below the extremes faced in Latin America. As shown below with a set of non-income development indicators in table 11.1 and figure 11.1, a generation of social leveling arguably took place in the postwar era, with positive trends lasting into the subsequent neoliberal period.

As a social compact, however, corporatism contained at least three contradictions that intensified over time. First, a sharp urban bias sat at its core. Even where living standards rose in the countryside from land reforms, rural migrants flocked to cities in search of higher wages in the form of cash income. With the rise in population due to investments in public health, urban bias led to a relative depeasantization of the region. The increasing scale of subproletarian life in urban areas was impossible to absorb into the state and semi-state apparatus, much less govern in a systematic manner. The response by MENA states was to implement systems of subsidies and price ceilings for staple goods and fuel. Inefficient in structure and regressive in absolute terms of total distribution, but progressive in terms of household consumption effects, subsidies were the only universal social policy in the Middle East other than primary education. They were blunt but effective forms of social protection-an understandable approach by states that did not possess the capacity to make their populations "legible" enough to target with anti-poverty 


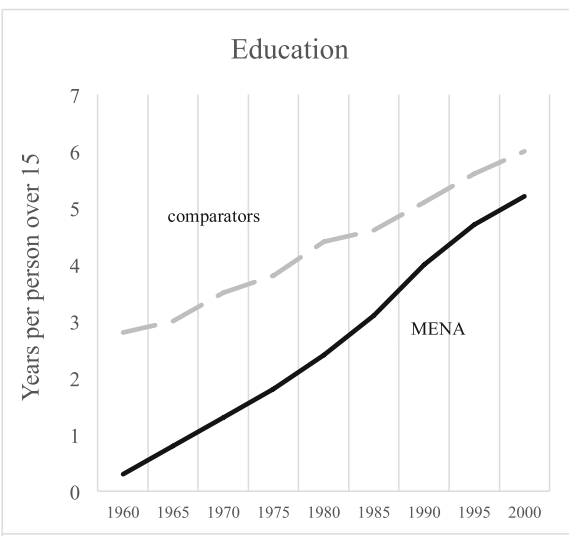

Child mortality

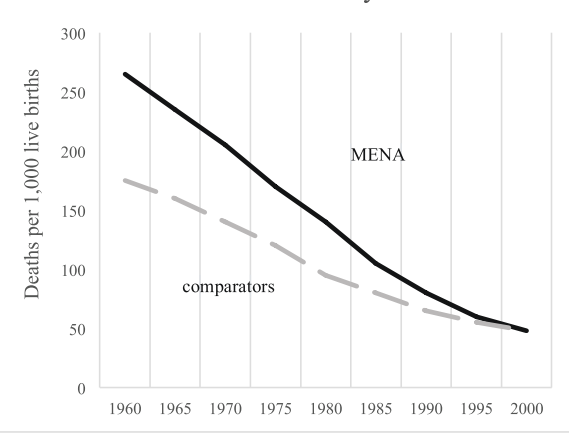

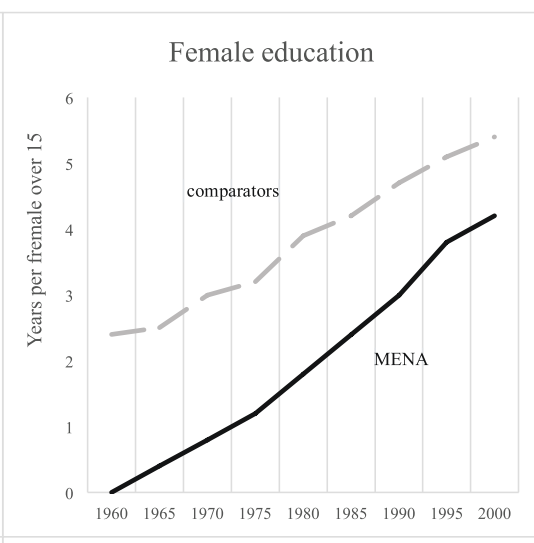

Life expectancy

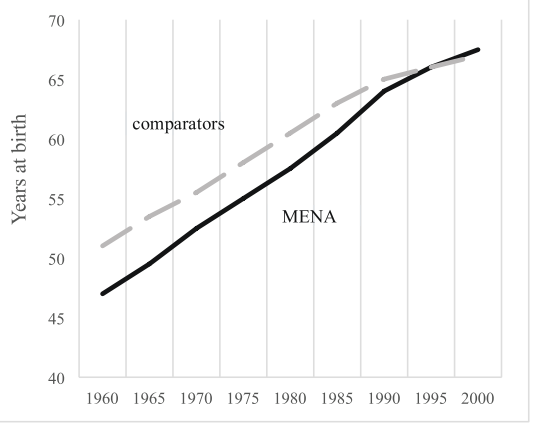

FIGURE 11.1. Comparative trends in human development indicators, Middle East and North Africa, 1960-2000. Data from combined averages of ten MENA states (Algeria, Egypt, Iran, Jordan, Lebanon, Libya, Morocco, Syria, Tunisia, and Yemen) and thirty non-MENA comparators (defined as middle-income countries in 1980).

SOURCE: Farrukh Iqbal, Sustaining Gains in Poverty Reduction and Human Development in the Middle East and North Africa (Washington, DC: World Bank, 2006), 24.

TABLE 11.1 Human development indicators for MENA 10, 1960-2000. (Data from combined averages of ten MENA states-Algeria, Egypt, Iran, Jordan, Lebanon, Libya, Morocco, Syria, Tunisia, and Yemen. See Farrukh Iqbal, Sustaining Gains in Poverty Reduction and Human Development in the Middle East and North Africa (Washington, DC: World Bank, 2006), 23.

\begin{tabular}{lccc}
\hline \multicolumn{1}{c}{ Indicator } & $\mathbf{1 9 6 0}$ & $\mathbf{1 9 8 0}$ & $\mathbf{2 0 0 0}$ \\
\hline Years of education (average per person over fifteen) & 0.9 & 2.6 & 5.5 \\
Years of education (average per female over fifteen) & 0.5 & 1.8 & 4.6 \\
Child mortality (deaths per 1,000 births) & 262 & 138 & 47 \\
Life expectancy & 47 & 58 & 68 \\
\hline
\end{tabular}


programs. After a generation, low prices for commodities became understood as citizenship rights, not state privileges. As population and urbanization increased, the relative weight of subsidies in state budgets also increased. ${ }^{25}$ Here lay the social setting for the so-called International Monetary Fund riots in Egypt and Tunisia of the late 1970s and early 1980s, when these states attempted and then balked at raising prices on subsidized goods. Eventually, most MENA states would open up the countryside to capitalist agriculture after the 1980s, which pushed another generation into the cities. ${ }^{26}$

Second, staple subsidies and import substitution industrialization put increasing pressure on MENA states' balance of payments. There was no single source of stable foreign exchange with which to buy capital goods from wealthy countries: migration remittances, oil-money transfers, and agrarian surpluses were all too volatile and dependent on cyclical fluctuations in the world economy. The easy phases of manufacturing, from textiles to consumer goods to auto assembly, had pushed up against the demand limits of the domestic market. The OPEC price hikes of the 1970 s could have, hypothetically, produced the capital to fund a campaign to sustain a region-wide diversified industrialization strategy. That capital, however, largely ended up in the hands of financiers in London and New York, with Beirut as a secondary beneficiary, due to its regional entrepôt function.

Third, even with the exclusionary form of corporatism practiced by MENA states, wherein entry to formal-sector employment was limited, middle-stratum beneficiaries began to protest. If the corporatist social compact was limited on the outside by the extent of public-sector expansion, it was limited on the inside by the empowerment of middle-stratum workers and professionals who demanded the democratization of that social compact. This resulted in a regional wave of "unruly corporatism." In countries where "authoritarian elites have attempted to force associational life into a tighter state corporatist mold their regimes have been deeply shaken or overturned by unanticipatedly powerful oppositions." ${ }^{27}$ From Iran to Egypt to Syria to Algeria, these oppositions took secular and religious forms-or sometimes an amalgam-but they all shared similar social bases. In short, MENA corporatism produced its own gravediggers through the twin processes of proletarianization and professionalization. Hardly the stabilizing "authoritarian bargain" pronounced by Western analysts, by the late 1970s the social compact was being reassessed by elites and masses across the region.

What of the smaller oil-producing states (and city-states)? Though Saudi Arabia had won its independence in the 1930s, some of the littoral Gulf states had come into formal sovereignty only by the 1970s, such as the United Arab Emirates or Qatar. In most of these territories, an oligarchy of mercantile chiefdoms had long ruled, with migrant labor utilized in the pearling and portage industries. British patronage and preference led to the rise of selected families as state rulers by the late 1930s. Yet unlike in West Asia and North Africa, the Arabian Peninsula was 
penetrated earlier by U.S. corporate capital, though limited to select sites. In Saudi Arabia, labor regulation was borrowed not from the Kemalist model of Turkey, but from the racialized model of the United States. U.S. firms such as ARAMCO exported labor practices from U.S. mining and oil sectors to the Gulf oilfields, with hierarchical tiers of pay and benefits for white versus nonwhite labor. The same practices occurred in U.K.-established oil-company towns in southern Iran and Iraq, but in those areas, nationalization put an end to racial stratification of labor. Not so in the Arabian Peninsula, where state-led development codified a tiered racial citizenship in key zones of production well into the 196os, underpinned by a hard gender division of labor. As the Gulf increased in political and economic relevance during the late twentieth century, this citizenship regime spread as a peninsular model. ${ }^{28}$ These states' legitimacy rested on a combination of invented tradition and spectacular forms of outwardly displayed modernization. Kinship lineages became vital for bounded citizenship and informal networks of capital accumulation that spilled over into large Arab states in the 1970s. The Gulf sheikdoms are not tribal throwbacks by any means, but a subcategory of semi-peripheral state formation. ${ }^{29}$

By the late 1970s, then, the social compact in most MENA states appeared similar irrespective of ideological persuasion. Its outlines were a relatively large public sector with corporate linkages to various subaltern groups, an expansion of primary health and education to most of the population, a subsidization of staple goods and services for urban classes, and a piecemeal land reform tailored toward strategies of import-substitution industrial growth. Each of these segments underwent partial liberalization from the 1980 os onward. In Arab states, the overall approach was labeled infitah: openness.

\section{The Infitah Years}

Asserting that the Middle East's main dilemma is neoliberalism-that this was the cause of the 2011 Arab uprisings, for instance-tells us little about the key dynamics of recent decades. During this period, the MENA region was not subject to external or internal pressures of neoliberalization to the extent that occurred in most of sub-Saharan Africa or Latin America. Arab states did not actively dismantle their welfare systems as much as let them ossify. Non-state entities moved into these states' widening gaps of service provision. Turkey and Iran expanded their social compacts due to intra-elite factional politics and continued reliance on popular mobilization. Gulf monarchies, lastly, cordoned off access to social citizenship while actively regulating flows of disposable migrant labor.

Two factors help explain why the region was less subject to the dictates of the neoliberal wave of the 1970s-200os. First, after the Sino-U.S. détente and denouement of the Vietnam War, the main theater of military buildup, geopolitical conflict, and mass warfare shifted from East Asia to the MENA region. For most MENA political elites, and no matter the side of the conflict, war and war 
preparation served as a useful excuse to fight off technocratic efforts to shrink the state's budget and privatize national "mother" industries. When state elites did eventually engage in such activities, they did so dragging their feet, a half-hearted neoliberalism at best.

Second, even though many MENA states were not oil producers, the commodity bubbles of the 1970s generated sufficient intra-regional transfers of capital, which enabled states to keep segments of corporatist welfare systems in place. These capital flows, coupled with new sources of external finance for MENA states, prevented the deep balance-of-payments crises that Latin America and sub-Saharan Africa experienced in the 1980s and 1990s and allowed for the continued use of the public sector as a provider of employment and status attainment. Jordan's public sector, for instance, employed more people in the 2ooos than in the 1980s. Egypt's public-sector salaries rose, rather than fell, over the same period..$^{30}$ To this must be added U.S. flows of military and development aid that buffered political elites in U.S.-friendly states, such as Egypt and Jordan, from ever being removed, no matter the internal situation. Neoliberal elites abound in the Middle East, well received among the chattering classes of Northern countries. But they arguably never held the reins of power for a long period in anywhere but Turkey, and there were no crises deep enough to allow the takeover of Arab states and purging of old guards until the 2011 protests.

Given that many of these states' association with a hazy secular-left discourse was embedded in the popular imagination, Islamist movements could more easily take advantage of oppositional politics as disillusionment with these states' social compacts mounted. The main beneficiaries of the postwar MENA social compact were the middle urban strata created by and linked with state-led development. As states began to experiment with piecemeal liberalization, cleavages within these middling groups appeared. Political Islam in most Arab states was a phenomenon with middle-class roots, often linked through university and professional associations. Rarely developed within the seminary traditions of teaching jurisprudence, political Islam largely originated outside of existing religious institutions. Lay individuals who had amassed prestige in other social spheres also laid claim to the application of spiritual knowledge toward social and political reform. Though traceable back to the late nineteenth century, political Islam in the late twentieth century possessed divisions homologous with its radical secular cousins. There were Leninist-type institutions, vertically organized and based on seniority, the most successful (and exportable) being Egypt's Muslim Brothers. And there were more anarchic, cellular organizations, often revolving around a charismatic spiritual guide, which appeared from mid-century onward. ${ }^{31}$

Arab states' relations with these Islamists were instrumental at best, often seen as a tool to harass or compete with the left. When the 1979 Iranian revolution produced an Islamic-garbed state to replace a crucial ally of the United States, political Islam received a wave of prestige among many who knew little about Iran or Shi'a 
Islam at all. The Soviet invasion of Afghanistan produced another "international" of Islamists whose varying ideological persuasions collectively cascaded toward a Saudi-supported salafism. These two waves of rebellion sometimes flowed in tandem, but occasionally crashed into each other. ${ }^{32}$ Yet the main driver of Islamist success was discontent with the status quo and existing alternatives, given the failed communist rebellions in the MENA region. As an amorphous framework that could equally glom onto Third International Marxism, Third Worldist nationalism, or High Street banking, political Islam gave the added benefit of providing a regional touchstone to the nativist promise of a region-wide renewal..$^{33}$

These intellectual streams circulated while Arab states slowly peeled away layers of the public sector. Instead of applying shock therapy, Arab states shuffled off state sectors in piecemeal fashion. The result was a long decline in public investment with no concurrent uptick in private investment. Since 1985, the ratio of fixed investment/GDP in MENA states has remained between 20 percent and 25 percent. East and South Asian investment rates matched and then surpassed the MENA region in the 1980 s and 2000 , respectively. ${ }^{34}$

The OPEC "revolution" that washed Gulf states in capital did not produce a deluge of investment toward populous MENA countries. Under a different geopolitical order, perhaps, after the 1967 and 1973 Arab-Israeli wars these incoming revenues could have been converted into a regional equivalent to the Marshall plan. The real sink of Gulf capital was, however, Euro-U.S. financial markets, part of which then flowed back to Third World countries in the form of Wall Street private lending. ${ }^{35}$ The Gulf capital that did travel to MENA states was targeted toward activities that barely distinguished it from Western capital-namely, finance and real estate-thus evading state clutches and making it harder to repurpose for state-defined developmental goals. The form of business enterprise attached to Gulf capitalism, the diversified business conglomerate, was often portrayed as a traditional monarchical throwback. This trope hid the fact that family-held holding companies and state-linked conglomerates were the most common form of capital accumulation across the North and the South, globally thriving in neoliberal habitats. ${ }^{36}$

Amid the din, the hidden success story of Arab MENA states during the global neoliberal turn was a marked continuation in improvement of non-income welfare levels at a pace commensurate with the postwar statist period. This occurred while, relative to wealthy Northern states, per capita income levels stagnated and then declined. Between 1985 and 2000, the World Bank reported, MENA "developing" countries outperformed other middle-income regions in the Global South in their improvement of schooling years, literacy levels, child mortality, and life expectancy. This occurred, the World Bank puzzled, "despite a considerably slower rate of output growth and a decline in levels of public spending." ${ }^{37}$ In fact, compared to countries at similar income levels, MENA states performed far more poorly in 
terms of income growth from 1980 to 2000 , but their non-income welfare indicators caught up with comparators (shown above in table 11.1 and figure 11.1).

It is indeed puzzling, and the development literature on the region itself contains no consensus to account for the data. The convergence of MENA with other regions on non-income welfare indicators is observed even when controlling for levels of income and public spending..$^{38}$ A provisional explanation is that the differentia specifica of the region for its non-income basic welfare successes was the absence of full-throttled neoliberalism. An ossifying yet intact public sector was arguably better than one subject to neoliberal strictures. In a weak state system such as that of Lebanon, private spending on health and education was the norm even in the postwar years. Yet in those Arab states with a legacy of large public sectors, private spending did not serve as a replacement for public services. Given the deepening underinvestment in the state, however, two glaring fissures appeared. The quality of service suffered, leading to increased private welfare spending on top of existing social provisions. Also, access to advanced health care, as in most countries, was limited to those with social insurance-mainly public-sector workers and the wealthier elite. The welfare institutions of the previous era were never upgraded or expanded. ${ }^{39}$

For Iran and Turkey, a breakdown in postwar elite rule-by the 1979 revolution and the 1980 coup, respectively-resulted in a process of unstable intra-elite competition. For all the well-known differences between the two countries, one common fact stands out. This elite competition allowed for newly mobilized social groups to force demands onto the state. Turkey's Justice and Development Party (AK Party) was the most successful actor of them all, wielding a long-curated popular mobilization to eventually transform the political structures of the Kemalist republic. In the process, the uneven corporatist pillars of the welfare system were remolded into a broader-though more fragile-social protection regime that mixed market, state, and non-state actors. $4^{40}$ In Iran, continual jockeying within a fractious postrevolutionary elite resulted in the proliferation of new welfare organizations and inclusionary social provisions. Yet the inability of the state to robustly enforce such regulations has produced a mixed welfare regime where casualization occurs alongside expanding social insurance protection..$^{41}$ Nevertheless, in both cases, there has been a marked change in social protection systems over the past decade, as new segments of the population have been provided access to state welfare.

\section{A TIME OF MONSTERS}

Given the positive trends mentioned above, why did the Arab uprisings occur? Improvements in non-welfare indicators are not incommensurate with political unrest. Indeed, coupled with lack of income convergence with the wealthy North, 
especially in light of the rapid economic growth in other Southern regions and growing inequality between MENA subregions, grievances were plenty. Given increases in health and education, as well as a concurrent demographic transition toward nuclear household sizes, exit and voice were prevalent strategies among those who felt blocked from pathways of upward mobility available to previous MENA generations. A common option was, as always, migration. Yet North African migration to southern Europe as well as the Gulf increasingly came under harsh constraints- "fortress Europe" in the former, a switch to South Asian labor under the latter. The classic political safety valve of migration was, for these countries, increasingly obstructed.

Some of the social grievances highlighted in the 2011 Arab uprisings, however, stem from problems that arose from earlier successes. Mass primary education and basic health care were pro-poor interventions by the state. From 1975 to 2010, Arab MENA states enjoyed the fastest rate of growth of average years of schooling of any region. Fertility rates declined and spending per child increased in households. As a result, the subsequent generation's horizons toward education were starkly different than that of their parents. Yet on the tertiary level and in the labor market, class inequality was reproduced. Quantitative gains in educational attainment masked the qualitative avenues of elite status distinction that reduced the returns on so-called human capital. Even more structural factors were at play. The baby boom of the 1970s-1980s meant that the number of youth entering the working age circa 2010 was four to six times that of people reaching retirement age. The ossification of public investment channeled the search for employment toward private forms, usually informal. Reservation wages tended to be higher than other Southern countries, with little incentive for foreign capital to hire skilled or technical labor. ${ }^{42}$ These particulars lay under the relatively high formal unemployment rates for youth in the region when compared to other Southern countries. As a result, many young individuals faced a "failure to launch."

This social stratum is awkward to classify in theoretical terms. Carrie Wickham has labeled such individuals in Egypt as the lumpen intelligentsia, a "professional underclass" with "graduates unable to find permanent white-collar employment... not unemployed so much as forced to accept jobs they perceived as beneath the dignity of someone with a university degree." ${ }^{43}$ While the 2011 uprisings had roots in earlier formal-labor protests, this new stratum was present throughout the initial protest wave across the region. ${ }^{44}$

Fortunately, on account of questions added to the 2011 Arab Barometer Survey in Tunisia and Egypt, survey data exists that details some of the contours of unrest in these two best-known cases. Protest participants in both countries tended to be mostly male, with above average income and education levels. Forty-six percent of surveyed protestors in Egypt, for instance, had at least some university education, compared to 19 percent of the population as a whole. Unemployment 
was not a predictor of protest, nor was youth, but protestors disproportionately possessed professional and skilled vocational backgrounds compared to the rest of the population. More unskilled workers protested in Tunisia than in Egypt, the surveys found, but in both cases, there was a disproportionately high rate of protest participation by government employees. Women who did participate tended to be active in the labor market. The younger the age of the protestor, the more likely he or she was to identify economic grievances or corruption rather than civil and political freedoms as the key motivation for participation. ${ }^{45}$ Snapshot surveys cannot capture questions of timing and process in the two countries' uprisings, but they do give some weight to the lumpen intellgentsia's role as compared to the formalized proletariat or informal sub-proletariat.

As a sop to the poorest strata, MENA Arab states did not fully liberalize their subsidies on staple goods and fuel. The increasing trend, in line with other regions, has been to replace segments of the subsidy system with new "targeted" antipoverty programs. Unlike in Latin America, these are relatively new, small-scale, and disconnected from party mobilization. Along with decreased spending on public housing and infrastructure, the erosion of the previously established social compact has contributed to the informalization and casualization of the domestic labor force, including disguised female labor.

If there is an overriding factor determining the trajectory of MENA states, however, it is not neoliberalism as much as militarism. While sporadic wars had taken place in the region after 1948, since the 1970 s there has been a long cascading war with multiple sub-currents. At least three varieties can be distinguished. First are national-expansionist projects under U.S. protection-Israel in Palestine, Lebanon, Syria, the Sinai; Iraq into Iran; Saudis in Yemen; and Iranian soft expansionism in Afghanistan and Iraq. Second are national-expansionist projects without U.S. protection-Iraq into Kuwait. Third, and most widespread, are conflicts with a popular-war dynamic, where social discontent has combined with national anger-Palestinian intifadas, Yemeni oppositions, Hezbollah, the Kurdish Workers' Party, and Sunni militias in Iraq-which often become entangled with internal security struggles and temporary external alliances. This semipermanent state of war and increasingly direct intervention by U.S. military forces set the stage for a series of counter-revolutions after 2011 to contain the wave of mass uprisings.

The other outcome of this war cascade was to push the political and economic leadership of MENA states toward the Gulf monarchies. The Gulf model attempted to create a costless, codified capitalism: social citizenship for elite kinship minorities, imported professional and working classes, and territorial security subcontracted to the American superpower. Celebrated by sycophants and held up as an obverse to state-led development, the model is under strain on all three fronts. Young Gulf Arabs are growing tired of being cloistered and pampered without career trajectories, leading the monarchies to pursue a half-hearted policy 
of "nationalization" of the workforce, with increased costs in tow. The long-term circulation of South Asian and North African labor throughout the Gulf has built up local communities with their own resources of social solidarity. Hidden resistance is still the norm, but costs of containing labor unrest are increasing. The U.S. protection umbrella, as the royals are now grumbling, is looking more like a protection racket. But if the Gulf monarchies had to protect themselves, they would also have to enter into a more ordinary balance of power in the region where Iran, Turkey, and other possible competitors could claim a veto irrespective of American or Israeli wishes. This has occurred to some extent anyway, making the Gulf model even more precarious.

Like the 1848 revolutions, the 2011 uprisings brought forth a reactionary wave of violent containment, as well as bargained co-optation. Yet if authoritarian retrenchment were again the main outcome, the situation would be less dire. In the decade and a half since the U.S. invasion of Iraq, segments of the postwar MENA political order shifted back toward the politics of notables, local social formations, and transnational flows of pamphlets, laborers, and revolutionaries. In the previous iteration of this, in the early twentieth century, it took waves of antielite, anticolonial mobilization, as well as radical political state-building projects, to produce order from the mayhem. For the time being, however, the chances of a repeat look rather slim.

Instead, as occurred in Afghanistan during the 1980s and 1990s, coherent and crafted political systems along the Maghreb and Levant are being pulverized into a set of rump chieftaincies. The labor reserves that had been accumulating during the shrinking of the state- unskilled proletarians and skilled professionals alikeare now the uprooted migrants that sit in the shatter zones of the old geopolitical order. As reported in the London Review of Books, "The mobilisation techniques used in the Arab Spring, which brought thousands of demonstrators to a given place, were now being used to organise the new waves of migration." ${ }^{6}$ Increases in health and educational attainment produced in postwar social compacts are being reversed for a generation. It remains to be seen if outstanding regional powers can prevent their own further entanglement or if additional conflagrations will arise.

If some form of cold peace comes to the region after further population resettlement, new social questions for the MENA region might revolve around centers of state power and capital accumulation, their exploited peripheries of inclusion, and the excluded remainder. Competitive spheres of influence are not necessarily antidevelopmental, if order is established and new cadres are developed. Any stability might come in the region only when states build political and social compacts that not only incorporate wider segments of the population but also significantly reshape their life chances. It is unlikely, though, that emulating the developmental models of the present will create a solid compact for MENA states. Processes of urbanization and depeasantization that were corollaries of MENA state formation meant that rural reserves of semi-proletarian labor of the sort that fueled rapid 
growth in East Asian markets and lured in Western capital are today nowhere to be found. The rural subsidization of social reproduction cannot be re-created. As Faruk Tabak insightfully pointed out, access to plantation labor attracted Western capital flows in the late nineteenth century, while access to rural networks of semiproletarian labor in East Asia supported the manufacturing activities in which global capital invested in the late twentieth century. The Ottoman Empire lacked the former, and today the Middle East lacks the latter. ${ }^{47}$

\section{NOTES}

1. Ian Lustick, "The Absence of Middle Eastern Great Powers: Political 'Backwardness' in Historical Perspective," International Organization 51, no. 4 (1997): 653-83.

2. Juan Cole, "Al-Tahtawi on Poverty and Welfare," in Poverty and Charity in Middle Eastern Contexts, ed. Michael David Bonner, Mine Ener, and Amy Singer (Albany: State University of New York Press, 2003), 225.

3. Timur Kuran, The Long Divergence: How Islamic Law Held Back the Middle East (Princeton, NJ: Princeton University Press, 2011); Lisa Blaydes and Eric Chaney, “The Feudal Revolution and Europe's Rise: Political Divergence of the Christian West and the Muslim World before 1500 CE," American Political Science Review 107, no. 1 (2013): 16-34.

4. Marshall Hodgson, The Venture of Islam, vol. 2 (Chicago: University of Chicago Press, 1974), 124.

5. Historical calculations of the Gini coefficient-zero representing perfect equality and one representing perfect inequality-are rough proxies for the concept of social inequality but still can function to compare across space and time, as long as the underlying data is put into context. For these particular measurements, see Colette Establet, Jean-Paul Pascual, and André Raymond, "La mesure de l'inegalite dans la societe ottomane: Utilisation de l'indice de Gini pour Le Caire et Damas vers 1700," Journal of the Economic and Social History of the Orient 37, no. 2 (1994): 171-82; Boğaç Ergene and Ali Berker, "Wealth and Inequality in 18th-Century Kastamonu: Estimations for the Muslim Majority," International Journal of Middle East Studies 40, no. 1 (2008): 23-46.

6. Şevket Pamuk, "Political Power and Institutional Change: Lessons from the Middle East," Economic History of Developing Regions 27, no. S1 (2012): S41-56.

7. Mine Ener, "The Charity of the Khedive," in Poverty and Charity in Middle Eastern Contexts, ed. Michael David Bonner, Mine Ener, and Amy Singer (Albany: State University of New York Press, 2003), 185-201.

8. Xaiver de Planhol, "Famines," Encyclopedia Iranica, online edition, 2012, www.iranicaonline. org/articles/famines.

9. Cemil Aydin, The Politics of Anti-Westernism in Asia: Visions of World Order in Pan-Islamic and Pan-Asian Thought (New York: Columbia University Press, 2007).

10. The 1812 Anglo-Persian treaty stipulated that Persia would oppose any European army that attempted to invade India via Central Asia.

11. Sükrü Hanioglu, A Brief History of the Late Ottoman Empire (Princeton, NJ: Princeton University Press, 2008), 89-92.

12. Faruk Tabak, "The Middle East in the Long Twentieth Century," in The Long Twentieth Century: The Great Divergence: Hegemony, Uneven Development, and Global Inequality, ed. Jomo Kwame Sundaram (New Delhi: Oxford University Press, 2006), 146-47.

13. Michael Reynolds, Shattering Empires: The Clash and Collapse of the Ottoman and Russian Empires 1908-1918 (Cambridge: Cambridge University Press, 2011).

14. Joel Beinin, Workers and Peasants in the Modern Middle East (Cambridge: Cambridge University Press, 2001), 77-80. 
15. See James Mahoney, Colonialism and Postcolonial Development: Spanish America in Comparative Perspective (Cambridge: Cambridge University Press, 2010).

16. Cyrus Schayegh, The Middle East and the Making of the Modern World (Cambridge, MA: Harvard University Press, 2017).

17. Eighty-five percent of Turkish agricultural holdings in 1963 were owner-operated, most of which were family farms under ten hectares ( 24.7 acres), up from 73 percent in 1950 . Beinin, Workers and Peasants in the Modern Middle East, 122.

18. Eric Hooglund, Land and Revolution in Iran, 1960-1980 (Austin: University of Texas Press, 1982).

19. Hanna Batatu, The Egyptian, Syrian, and Iraqi Revolutions: Some Observations on Their Underlying Causes and Social Character (Washington, DC: Georgetown University Center for Contemporary Arab Studies, 1984), 3.

20. James Gelvin, “The 'Politics of Notables' Forty Years After," Middle East Studies Association Bulletin 40, no. 1 (2006): 19-29

21. Gilbert Achcar, The People Want: A Radical Exploration of the Arab Uprising (Berkeley: University of California Press, 2013), 69.

22. See Beth Baron, "Islam, Philanthropy, and Political Culture in Interwar Egypt: The Activism of Labiba Ahmad," in Poverty and Charity in Middle Eastern Contexts, ed. Michael David Bonner, Mine Ener, and Amy Singer (Albany: State University of New York Press, 2003), 239-54.

23. Carrie Wickham, Mobilizing Islam: Religion, Activism, and Political Change in Egypt (New York: Columbia University Press, 2002), 25.

24. Nemat Shafik, Claiming the Future: Choosing Prosperity in the Middle East and North Africa (Washington, DC: World Bank, 1995).

25. For instance, Egypt spent 20 percent of the total budget on food subsidies alone in the late 1970s. Farrukh Iqbal, Sustaining Gains in Poverty Reduction and Human Development in the Middle East and North Africa (Washington, DC: World Bank, 2006), 57-69.

26. Habib Ayeb and Ray Bush, "Small Farmer Uprisings and Rural Neglect in Egypt and Tunisia," Middle East Report 272 (2014): 2-11.

27. Robert Bianchi, Unruly Corporatism: Associational Life in Twentieth-Century Egypt (New York: Oxford University Press, 1989), 25.

28. See Robert Vitalis, America's Kingdom: Mythmaking on the Saudi Oil Frontier (Stanford, CA: Stanford University Press, 2006).

29. Nadav Samin, Of Sand and Soil: Genealogy and Tribal Belonging in Saudi Arabia (Princeton, NJ: Princeton University Press, 2015).

30. Oliver Schlumberger, "Opening Old Bottles in Search of New Wine: On Nondemocratic Legitimacy in the Middle East," Middle East Critique 19, no. 3 (2010): 245-46.

31. Carrie Wickham, The Muslim Brotherhood: Evolution of an Islamist Movement (Princeton, NJ: Princeton University Press, 2013); Hazim Kandil, Inside the Brotherhood (Cambridge: Polity, 2014).

32. See the final comments by Suleiman Mourad, "Riddles of the Book," New Left Review, II, no. 86 (2014): 15-52.

33. Thanks to James Gelvin for this point; also see Sami Zubaida, Beyond Islam: A New Understanding of the Middle East (London: I. B. Tauris, 2011), chap. 4.

34. Achcar, The People Want, 38-40.

35. Giovanni Arrighi, The Long Twentieth Century: Money, Power, and the Origins of Our Times (London: Verso, 1994), 333-35.

36. Adam Hanieh, Capitalism and Class in the Gulf Arab States (New York: Palgrave, 2011).

37. Iqbal, Sustaining Gains, xix.

38. Iqbal, Sustaining Gains, chap. 2.

39. See the essays in Ragui Assaad and Caroline Krafft, eds., The Egyptian Labor Market in a Time of Revolution (Oxford: Oxford University Press, 2016). 
40. In a comparative frame, Turkey looks most like southern European welfare regimes. See Ayşe Bugra and Aysen Candas, "Change and Continuity under an Eclectic Social Security Regime: The Case of Turkey," Middle Eastern Studies 47, no. 3 (2011): 515-28.

41. Kevan Harris, A Social Revolution: Politics and the Welfare State in Iran (Oakland: University of California Press, 2017).

42. Djavad Salehi-Isfahani, The Role of the Family in Social Integration in the Middle East and North Africa (DIFI Family Research and Proceedings, 2013), 5.

43. Wickham, Mobilizing Islam, 54.

44. See the contribution of labor unrest in the long left tail of the protest curve in Joel Beinin, Workers and Thieves: Labour Movements and Popular Uprisings in Tunisia and Egypt (Stanford, CA: Stanford University Press, 2015).

45. Mark Beissinger, Amaney Jamal, and Kevin Mazur, "Explaining Divergent Revolutionary Coalitions: Regime Strategies and the Structuring of Participation in the Tunisian and Egyptian Revolutions," Comparative Politics 48, no. 1 (2015): 1-24.

46. Ghaith Abdul-Ahad, "Some Tips for the Long-Distance Traveller," London Review of Books, October 8, 2015.

47. Tabak, "Middle East in the Long Twentieth Century," 165. 